\begin{tabular}{ll}
\hline \hline MINING AND METALLURGY INSTITUTE BOR & ISSN: 2334-8836 \\
& UDK: 622 \\
\hline \hline
\end{tabular}

Rodoljub Stanojlović, Jovica Sokolovic ${ }^{*}$

\title{
A STUDY OF FLOTATION KINETICS OF THE HYDROCYCLONE OVERFLOW AND UNDERFLOW IN THE PROCESSING OF HIGH-GRADE COPPER ORE ${ }^{* *}$
}

\begin{abstract}
The results of flotation kinetics the hydrocyclone underflow and overflow in high-grade copper ore processing from the Copper Mine Bor (RB Bor), suggest the possibility of improving the current technological flotation process. This is confirmed by the following results: the distribution of copper in classification product in ration 80:20\% in favor of hydrocyclone underflow as well as higher copper content in the sample and individual class of hydrocyclone underflow compared to the same parameters of hydrocyclone overflow.

Participation of optimal size class - $0.075 \mathrm{~mm}$ in hydrocyclone underflow is $32.47 \%$, with copper content of $4.38 \%$, resulting that about $65 \%$ of total copper in this class to the feed of hydrocyclone is distributed in hydrocyclone underflow and $35 \%$ in the same class in hydrocyclone overflow.

Copper recoveries, obtained in laboratory batch flotation tests from hydrocyclone overflow and underflow, are $90.77 \%$ and $7.94 \%$, respectively. Calculated in relation to total copper in the feed of hydrocyclone, $17.30 \% \mathrm{Cu}$ can be valorized from hydrocyclone overflow by flotation process, with the same process, $59.58 \% \mathrm{Cu}$ is valorized from hydrocyclone underflow, what is 3.44 times more.

The results indicate higher copper recovery and slightly better flotation kinetics of hydrocyclone overflow. However, due to better liberation of solid phase and optimization the pulp density in the flotation process, each class of hydrocyclone underflow gives higher contribution to the copper recovery compared to the relevant class of hydrocyclone overflow, calculated on copper, contained in the same class of hydrocyclone feed.

Parallel flotation of hydrocyclone overflow and underflow can improve the existing technological process of high-grade copper ore processing in the Copper Mine Bor.

Keywords: Copper Mine Bor, high-grade copper ore, hydrocyclone, overflow, underflow, flotation, kinetics.
\end{abstract}

\section{INTRODUCTION}

The increased average content of copper $(2-5 \% \mathrm{Cu})$ and gold $(1-7 \mathrm{~g} / \mathrm{t} \mathrm{Au})$, as well as significant difference in densities of these

components in relation to the density of associated aluminosilicate minerals, cause the reduced efficiency of hydrocyclone classifi-

\footnotetext{
*University of Belgrade, Technical Faculty Bor, V.J. 12, 19210 Bor, Serbia,

e-mail address: jsokolovic@tf.bor.ac.rs

*** This paper presents the results of the Projects TR 33007, "Implementation of Modern Techicaltechnological and Environmental Solutions in the Existing Production Systems of the Copper Mine Bor and Copper Mine Majdanpek” and TR 33038 “Improving Technology of Exploitation and Processing of Copper Ore with Monitoring the Living and Working Environment in the RTB Bor Group", funded by Ministry of Education, Science and Technological Development of the Republic of Serbia. The authors are grateful to the Ministry for financial support.
} 
cation in high-grade copper ore processing. This occurrence causes that liberated and overground particles with higher density, copper minerals from 4100 to $5800 \mathrm{~kg} / \mathrm{m}^{3}$, gold about $19000 \mathrm{~kg} / \mathrm{m}^{3}$, instead of hydrocyclone overflow, are distributed in the hydrocyclone underflow and unnecessary back into the grinding process [1-5]. Negative consequences of technical and technological imperfections of hydrocyclone as a classifier are multiple, including: increasing of energy consumption and charge in the grinding process per ton of processed copper ore, reducing the capacity and overgrinding of useful components affects the recovery in e flotation process [1-5].

The mass distribution of solid phase and useful components in the industrial process was about 20 to $80 \%$ in favor of hydrocyclone underflow as well as the granulometric characteristics of classification products, indicating the insufficient efficiency of classification process.

By laboratory batch flotation tests of hydrocyclone overflow and underflow from the industrial process of high-grade copper ore are defined the technological parameters and flotation process kinetics.

Analysis the technological parameters and flotation kinetics, both on integrated classification products, hydrocyclone overflow and underflow and on narrow size classes, considering the industrial distribution of solid phase and useful components in them, enables a realistic assessment of research justification toward technological improvement of the existing flotation processes of high-grade copper ore.

\section{GRINDING AND CLASSIFICATION OF HIGH-GRADE COPPER ORE}

Two-stage wet grinding (rod and ball mill with classification in hydrocyclones operating in a closed cycle with ball mill) are the integral part of industrial processing of high-grade copper ore. Hydrocyclone overflow as the final product of grinding process is distributed in the flotation of copper and precious metals, and hydrocyclone underflow is returned to the grinding process in the ball mill. Grinding and classification of high-grade copper ore is shown in Figure 1.

Capacity of industrial processing of high-grade copper ore in the Copper Mine Bor is $80 \mathrm{t} / \mathrm{h}$. Designed fineness of the final grinding product is $60 \%$ with class participation $-0.074 \mathrm{~mm}$.

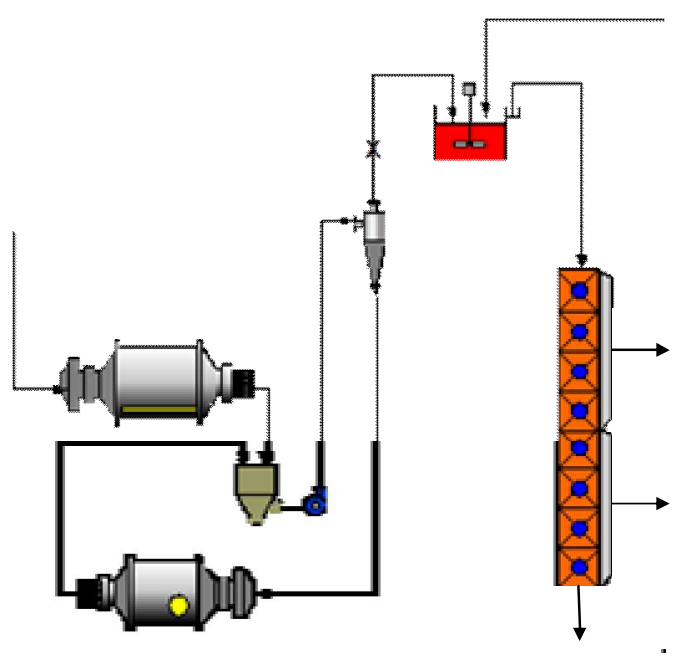

Figure 1 Flowsheet of grinding and classification process of high-grade copper ore 
Mass distribution of solid phase and useful components in the classification process, as well as grain size distribution and chemical composition of grinding products, i.e. hydrocyclone overflow and underflow were defined by recording the industrial process of grinding and classification the highgrade ore, Tables 1 and 2.

Table 1 Distribution of solid phase mass and useful components by classification products

\begin{tabular}{|c|c|c|c|}
\hline \multirow{2}{*}{ Product } & \multicolumn{3}{|c|}{ Distribution } \\
\cline { 2 - 4 } & Mass (\%) & Copper, Cu (\%) & Gold, Au (\%) \\
\hline Overflow & 19.99 & 19.05 & 9.77 \\
\hline Underflow & 80.01 & 80.95 & 90.23 \\
\hline Feed & 100.00 & 100.00 & 100.00 \\
\hline
\end{tabular}

Table 2 Grain-size distribution and chemical composition of hydrocyclone products

\begin{tabular}{|r|c|c|c|c|c|c|c|c|c|}
\hline \multirow{2}{*}{$\begin{array}{c}\text { Size class, } \\
(\mathbf{m m})\end{array}$} & \multicolumn{3}{|c|}{ Overflow } & \multicolumn{3}{c|}{ Underflow } & \multicolumn{3}{c|}{ Feed } \\
\cline { 2 - 10 } & $\mathbf{m}$ & $\begin{array}{c}\mathbf{C u} \\
(\boldsymbol{\%})\end{array}$ & $\begin{array}{l}\mathbf{R}_{\mathbf{C u}} \\
(\boldsymbol{\%})\end{array}$ & $\begin{array}{c}\mathbf{m} \\
(\boldsymbol{\%})\end{array}$ & $\begin{array}{c}\mathbf{C u} \\
(\boldsymbol{\%})\end{array}$ & $\begin{array}{c}\mathbf{R}_{\mathbf{C u}} \\
(\boldsymbol{\%})\end{array}$ & $\begin{array}{c}\mathbf{m} \\
(\boldsymbol{\%})\end{array}$ & $\begin{array}{c}\mathbf{C u} \\
(\boldsymbol{\%})\end{array}$ & $\begin{array}{c}\mathbf{R}_{\mathbf{C u}} \\
(\boldsymbol{\%})\end{array}$ \\
\hline+0.150 & 2.11 & 0.38 & 0.25 & 40.08 & 2.68 & 32.12 & 32.49 & 2.65 & 26.05 \\
\hline$-0.150+0.075$ & 13.65 & 0.65 & 2.82 & 27.45 & 3.09 & 25.37 & 24.69 & 2.82 & 21.07 \\
\hline$-0.075+0.038$ & 21.96 & 3.10 & 21.61 & 20.08 & 3.97 & 23.84 & 20.46 & 3.78 & 23.41 \\
\hline$-0.038+0.000$ & 62.28 & 3.81 & 75.32 & 12.39 & 5.04 & 18.67 & 22.36 & 4.36 & 29.47 \\
\hline Total: & $\mathbf{1 0 0 . 0 0}$ & $\mathbf{3 . 1 5}$ & $\mathbf{1 0 0 . 0 0}$ & $\mathbf{1 0 0 . 0 0}$ & $\mathbf{3 . 3 4}$ & $\mathbf{1 0 0 . 0 0}$ & $\mathbf{1 0 0 . 0 0}$ & $\mathbf{3 . 3 1}$ & $\mathbf{1 0 0 . 0 0}$ \\
\hline
\end{tabular}

\section{EXPERIMENTAL TESTING}

Flotation tests were carried out on the samples of hydrocyclone overflow and underflow from the industrial process of high-grade copper ore processing.

Standard flotation tests were carried out in laboratory machine DENVER DR12 with cell volume of 2,6 1. During this laboratory flotation batch tests, the impeller speed and aeration rate and $\mathrm{pH}\left(1300 \mathrm{~min}^{-1}\right.$ and $260 \mathrm{l} / \mathrm{min}$, respectively) were kept constant. $\mathrm{pH}$ was adjusted at about $\mathrm{pH} 10.5$. Solid content in a pulp (by weight) was constant of $25 \%$ in a flotation test with hydrocyclone overflow and $50 \%$ in a flotation test with hydrocyclone underflow. The reagents used in the kinetics test were collectors PEX (170 g/t in a flotation of hydrocyclone overflow) and PAX (350 g/t in a flotation of hydrocy-clone underflow) and Dowfroth D-250 as frother $(20 \mathrm{~g} / \mathrm{t})$. In each flotation kinetics test, the pulp was first agitated in the flotation cell for 10 minutes, after which the required dosage of flotation reagents was added and the slurry was conditioned one additional minute. The froth products were collected after 1, 3, 5, 10 and 20 minutes in the flotation. The froth flotation products were screened, filtered, dried and weighed. Chemical analyses were conducted for all size classes of flotation products. The results of mass distribution and copper by size classes of flotation products are shown in Tables 3 and 4. 
Table 3 Grain-size distribution and chemical composition of hydrocyclone overflow

\begin{tabular}{|r|r|c|r|r|r|r|r|r|r|}
\hline \multirow{2}{*}{$\begin{array}{c}\text { Size class, } \\
(\mathbf{m m})\end{array}$} & \multicolumn{3}{|c|}{ Concentrate } & \multicolumn{3}{|c|}{ Tailings } & \multicolumn{3}{c|}{ Feed (Overflow) } \\
\cline { 2 - 10 } & $\begin{array}{c}\mathbf{m} \\
(\boldsymbol{\%})\end{array}$ & $\begin{array}{c}\mathbf{C u} \\
(\boldsymbol{\%})\end{array}$ & $\begin{array}{c}\mathbf{R}_{\mathbf{C u}} \\
(\boldsymbol{\%})\end{array}$ & $\begin{array}{c}\mathbf{m} \\
(\boldsymbol{\%})\end{array}$ & $\begin{array}{c}\mathbf{C u} \\
(\boldsymbol{\%})\end{array}$ & $\begin{array}{c}\mathbf{R}_{\mathrm{Cu}} \\
(\boldsymbol{\%})\end{array}$ & $\begin{array}{c}\mathbf{m} \\
(\boldsymbol{\%})\end{array}$ & $\begin{array}{c}\mathbf{C u} \\
(\boldsymbol{\%})\end{array}$ & $\begin{array}{c}\mathbf{R}_{\mathbf{C u}} \\
(\boldsymbol{\%})\end{array}$ \\
\hline+0.150 & 0.24 & 1.92 & 0.16 & 1.87 & 0.18 & 1.17 & 2.11 & 0.38 & 0.25 \\
\hline$-0.150+0.075$ & 2.03 & 3.16 & 2.25 & 11.62 & 0.21 & 13.65 & 13.65 & 0.65 & 2.81 \\
\hline$-0.075+0.038$ & 10.34 & 6.26 & 22.66 & 11.62 & 0.28 & 21.96 & 21.96 & 3.10 & 21.60 \\
\hline$-0.038+0.000$ & 33.89 & 6.32 & 74.93 & 28.39 & 0.81 & 62.28 & 62.28 & 3.81 & 75.34 \\
\hline Total: & $\mathbf{4 6 . 5 0}$ & $\mathbf{6 . 1 4}$ & $\mathbf{1 0 0 . 0 0}$ & $\mathbf{5 3 . 5 0}$ & $\mathbf{0 . 5 4}$ & $\mathbf{1 0 0 . 0 0}$ & $\mathbf{1 0 0 . 0 0}$ & $\mathbf{3 . 1 5}$ & $\mathbf{1 0 0 . 0 0}$ \\
\hline
\end{tabular}

Table 4 Grain-size distribution and chemical composition of hydrocyclone underflow

\begin{tabular}{|r|c|c|c|c|c|c|c|c|c|}
\hline \multirow{2}{*}{$\begin{array}{c}\text { Size class, } \\
(\mathbf{m m})\end{array}$} & \multicolumn{3}{|c|}{ Concentrate } & \multicolumn{3}{c|}{ Tailing } & \multicolumn{3}{c|}{ Feed (Underflow) } \\
\cline { 2 - 10 } & $\begin{array}{c}\mathbf{m} \\
(\boldsymbol{\%})\end{array}$ & $\begin{array}{c}\mathbf{C u} \\
(\boldsymbol{\%})\end{array}$ & $\begin{array}{c}\mathbf{R}_{\mathbf{C u}} \\
(\boldsymbol{\%})\end{array}$ & $\begin{array}{c}\mathbf{m} \\
(\boldsymbol{\%})\end{array}$ & $\begin{array}{c}\mathbf{C u} \\
(\boldsymbol{\%})\end{array}$ & $\begin{array}{c}\mathbf{R}_{\mathbf{C u}} \\
(\boldsymbol{\%})\end{array}$ & $\begin{array}{c}\mathbf{m} \\
(\boldsymbol{\%})\end{array}$ & $\begin{array}{c}\mathbf{C u} \\
(\boldsymbol{\%})\end{array}$ & $\begin{array}{c}\mathbf{R}_{\mathbf{C u}} \\
(\boldsymbol{\%})\end{array}$ \\
\hline+0.150 & 10.86 & 3.49 & 15.36 & 29.22 & 2.35 & 79.04 & 40.08 & 2.68 & 31.94 \\
\hline$-0.150+0.075$ & 17.95 & 4.32 & 31.42 & 9.50 & 0.78 & 8.53 & 27.45 & 3.09 & 25.46 \\
\hline$-0.075+0.038$ & 16.89 & 4.49 & 30.72 & 3.19 & 1.22 & 4.48 & 20.08 & 3.97 & 23.89 \\
\hline$-0.038+0.000$ & 7.38 & 7.52 & 22.50 & 5.01 & 1.38 & 7.95 & 12.39 & 5.04 & 18.71 \\
\hline Total: & $\mathbf{5 3 . 0 8}$ & $\mathbf{4 . 6 5}$ & $\mathbf{1 0 0 . 0 0}$ & $\mathbf{4 6 . 9 2}$ & $\mathbf{1 . 8 5}$ & $\mathbf{1 0 0 . 0 0}$ & $\mathbf{1 0 0 . 0 0}$ & $\mathbf{3 . 3 4}$ & $\mathbf{1 0 0 . 0 0}$ \\
\hline
\end{tabular}

\section{COPPER FLOTATION KINETICS \\ FROM HYDROCYCLONE OVERFLOW AND UNDERFLOW}

In accordance with the aim of investigation on the hydrocyclone overflow and underflow, divided flotation tests were carried out in the selected time intervals. Each of the obtained concentrates and tailings were dried, weighted and screened for the flotation process of characteristic size class. Each size class of the individual concentrate and tailings, as a function of time, were analyzed on the copper content as the basic useful component.
Based on the obtained flotation test results, shown in Table 1-4, the values of copper recovery were calculated by narrow size classes, as well as the integral values, as a function of flotation time were used in defining the copper flotation kinetics from hydrocyclone overflow and underflow. The calculated values of technological parameters are given in Tables 5 and 6. 
Table 5 Grain-size distribution, chemical composition and technological parameters of divided flotation of hydrocyclone overflow

\begin{tabular}{|c|c|c|c|c|c|c|c|}
\hline \multirow{2}{*}{$\begin{array}{c}\text { Size class, } \\
\text { d (mm) }\end{array}$} & \multirow{2}{*}{ Products } & \multirow{2}{*}{$\underset{(\%)}{m}$} & \multirow{2}{*}{$\begin{array}{c}\mathrm{Cu} \\
(\%)\end{array}$} & \multirow{2}{*}{$\begin{array}{l}\mathbf{I}_{\mathrm{Cu}} \\
(\%)\end{array}$} & \multicolumn{3}{|c|}{$\mathbf{I}_{\mathrm{Cu}}(\%)$} \\
\hline & & & & & $\mathrm{I}_{\mathrm{k}}=100 \%$ & $\mathrm{I}_{\mathrm{u}}^{\mathrm{p}}=100 \%$ & $\mathrm{I}_{\mathrm{u}}{ }^{\mathrm{c}}=100 \%$ \\
\hline$+0,150$ & \multirow{4}{*}{$\mathrm{K} 1$} & 0,08 & 2,88 & 0,12 & 0,08 & 0,07 & 0,01 \\
\hline$-0,150+0,075$ & & 0,91 & 4,72 & 2,22 & 1,50 & 1,36 & 0,26 \\
\hline$-0,075+0,038$ & & 6,51 & 8,09 & 27,32 & 18,44 & 16,74 & 3,19 \\
\hline \multirow[t]{2}{*}{$-0,038+0$} & & 13,32 & 10,18 & 70,34 & 47,47 & 43,09 & 8,22 \\
\hline & & 20,82 & 9,26 & 100,00 & 67,49 & 61,26 & 11,68 \\
\hline$+0,150$ & \multirow{4}{*}{ K2 } & 0,09 & 1,82 & 0,26 & 0,06 & 0,05 & 0,01 \\
\hline$-0,150+0,075$ & & 0,64 & 2,43 & 2,52 & 0,54 & 0,49 & 0,09 \\
\hline$-0,075+0,038$ & & 2,68 & 3,95 & 17,21 & 3,70 & 3,36 & 0,64 \\
\hline \multirow[t]{2}{*}{$-0,038+0$} & & 9,20 & 5,35 & 80,01 & 17,23 & 15,64 & 2,98 \\
\hline & & 12,61 & 4,88 & 100,00 & 21,53 & 19,54 & 3,73 \\
\hline$+0,150$ & \multirow{4}{*}{ K3 } & 0,03 & 1,03 & 0,23 & 0,01 & 0,01 & 0,00 \\
\hline$-0,150+0,075$ & & 0,20 & 1,51 & 2,28 & 0,10 & 0,09 & 0,02 \\
\hline$-0,075+0,038$ & & 0,49 & 1,59 & 5,93 & 0,27 & 0,25 & 0,05 \\
\hline \multirow[t]{2}{*}{$-0,038+0$} & & 3,43 & 3,51 & 91,56 & 4,22 & 3,83 & 0,73 \\
\hline & & 4,15 & 3,17 & 100,00 & 4,60 & 4,18 & 0,80 \\
\hline$+0,150$ & K4 & 0,03 & 1,02 & 0,26 & 0,01 & 0,01 & 0,00 \\
\hline$-0,150+0,075$ & & 0,24 & 1,03 & 2,16 & 0,09 & 0,08 & 0,02 \\
\hline$-0,075+0,038$ & & 0,51 & 1,07 & 4,76 & 0,19 & 0,17 & 0,03 \\
\hline \multirow[t]{2}{*}{$-0,038+0$} & & 4,31 & 2,49 & 92,82 & 3,78 & 3,43 & 0,65 \\
\hline & & 5,09 & 2,27 & 100,00 & 4,07 & 3,69 & 0,70 \\
\hline$+0,150$ & K5 & 0,01 & 0,61 & 0,15 & 0,00 & 0,00 & 0,00 \\
\hline$-0,150+0,075$ & & 0,04 & 0,84 & 0,45 & 0,01 & 0,01 & 0,00 \\
\hline$-0,075+0,038$ & & 0,15 & 0,97 & 2,26 & 0,05 & 0,04 & 0,01 \\
\hline \multirow[t]{2}{*}{$-0,038+0$} & & 363 & 1,78 & 97,14 & 2,25 & 2,05 & 0,39 \\
\hline & & 3,83 & 1,74 & 100,00 & 2,31 & 2,10 & 0,40 \\
\hline$+0,150$ & $\sum \mathrm{K}$ & 0,24 & 1,92 & 0,16 & 0,16 & 0,14 & 0,02 \\
\hline$-0,150+0,075$ & & 2,03 & 3,16 & 2,25 & 2,25 & 2,03 & 0,39 \\
\hline$-0,075+0,038$ & & 10,34 & 6,26 & 22,66 & 22,66 & 20,56 & 3,92 \\
\hline \multirow[t]{2}{*}{$-0,038+0$} & & 33,89 & 6,32 & 74,93 & 74,93 & 68,04 & 12,97 \\
\hline & & 46,50 & 6,14 & 100,00 & 100,00 & 90,77 & 17,30 \\
\hline$+0,150$ & $\mathrm{~J}$ & 1,87 & 0,18 & 1,17 & & 0,11 & 0,02 \\
\hline$-0,150+0,075$ & & 11,62 & 0,21 & 8,40 & & 0,76 & 0,15 \\
\hline$-0,075+0,038$ & & 11,62 & 0,28 & 11,19 & & 1,03 & 0,20 \\
\hline \multirow[t]{2}{*}{$-0,038+0$} & & 28,39 & 0,81 & 79,24 & & 7,33 & 1,38 \\
\hline & & 53,50 & 0,54 & 100,00 & & 9,23 & 1,75 \\
\hline$+0,150$ & $\mathrm{U}$ & 2,11 & 0,38 & 0,25 & & 0,25 & 0,04 \\
\hline$-0,150+0,075$ & & 13,65 & 0,65 & 2,81 & & 2,79 & 0,54 \\
\hline$-0,075+0,038$ & & 21,96 & 3,10 & 21,60 & & 21,59 & 4,12 \\
\hline \multirow[t]{2}{*}{$-0,038+0$} & & 62,28 & 3,81 & 75,34 & & 75,37 & 14,35 \\
\hline & & 100,00 & 3,15 & 100,00 & & 100,00 & 19,05 \\
\hline
\end{tabular}


Table 6 Grain-size distribution, chemical composition and technological parameters of divided flotation of hydrocyclone underflow

\begin{tabular}{|c|c|c|c|c|c|c|c|}
\hline \multirow{2}{*}{$\begin{array}{l}\text { Grain size class, } \\
\quad \text { d }(\mathbf{m m})\end{array}$} & \multirow{2}{*}{ Products } & \multirow{2}{*}{$\mathbf{m}(\%)$} & \multirow{2}{*}{$\begin{array}{l}\mathrm{Cu} \\
(\%)\end{array}$} & \multirow{2}{*}{$\mathbf{I}_{\mathrm{Cu}}(\%)$} & \multicolumn{3}{|c|}{$\mathbf{I}_{\mathrm{Cu}}(\%)$} \\
\hline & & & & & $I_{k}=100 \%$ & $I_{u}{ }^{p}=100 \%$ & $I_{u}{ }^{c}=100 \%$ \\
\hline$+0,150$ & \multirow{4}{*}{ K1 } & 5,55 & 3,47 & 11,19 & 7,81 & 5,78 & 4,37 \\
\hline$-0,150+0,075$ & & 12,75 & 4,36 & 34,60 & 22,53 & 16,67 & 13,50 \\
\hline$-0,075+0,038$ & & 12,32 & 4,46 & 34,20 & 22,27 & 16,44 & 13,34 \\
\hline$-0,038+0$ & & 3,50 & 8,82 & 19,21 & 12,52 & 9,25 & 7,49 \\
\hline & & 34,12 & 4,71 & 100,00 & \begin{tabular}{|c|}
65,13 \\
\end{tabular} & 48,14 & 39,00 \\
\hline$+0,150$ & \multirow{4}{*}{ K2 } & 2,60 & 3,80 & 17,75 & 4,00 & 2,96 & 2,40 \\
\hline$-0,150+0,075$ & & 3,85 & 4,10 & 28,36 & 6,40 & 4,73 & 3,83 \\
\hline$-0,075+0,038$ & & 3,58 & 4,41 & 28,37 & 6,40 & 4,73 & 3,83 \\
\hline \multirow[t]{2}{*}{$-0,038+0$} & & 1,44 & 9,86 & 25,52 & 5,76 & 4,26 & 3,45 \\
\hline & & 11,47 & 4,85 & 100,00 & 22,56 & 16,68 & 13,51 \\
\hline$+0,150$ & \multirow{4}{*}{ K3 } & 1,30 & 3,95 & 29,81 & 2,08 & 1,54 & 1,25 \\
\hline$-0,150+0,075$ & & 0,91 & 5,04 & 26,67 & 1,86 & 1,38 & 1,11 \\
\hline$-0,075+0,038$ & & 0,69 & 5,35 & 21,44 & 1,50 & 1,11 & 0,90 \\
\hline \multirow[t]{2}{*}{$-0,038+0$} & & 0,53 & 7,18 & 22,08 & 1,54 & 1,15 & 0,92 \\
\hline & & 3,43 & 5,02 & 100,00 & 6,98 & 5,18 & 4,18 \\
\hline$+0,150$ & K4 & 1,18 & 2,66 & 32,81 & 1,27 & 0,94 & 0,76 \\
\hline$-0,150+0,075$ & & 0,38 & 3,77 & 14,94 & 0,58 & 0,43 & 0,35 \\
\hline$-0,075+0,038$ & & 0,24 & 4,93 & 12,33 & 0,48 & 0,35 & 0,29 \\
\hline \multirow[t]{2}{*}{$-0,038+0$} & & 0,90 & 4,25 & 39,92 & 1,55 & 1,15 & 0,93 \\
\hline & & 2,70 & 3,54 & 100,00 & $3, \mathbf{8 8}$ & 2,87 & 2,32 \\
\hline$+0,150$ & K5 & 0,23 & 2,06 & 13,13 & 0,19 & 0,14 & 0,11 \\
\hline$-0,150+0,075$ & & 0,06 & 1,82 & 3,07 & 0,04 & 0,03 & 0,03 \\
\hline$-0,075+0,038$ & & 0,06 & 3,04 & 5,03 & 0,07 & 0,05 & 0,04 \\
\hline \multirow[t]{2}{*}{$-0,038+0$} & & 1,01 & 2,79 & 78,77 & 1,15 & 0,85 & 0,69 \\
\hline & & 1,36 & 2,63 & 100,00 & 1,45 & 1,07 & 0,87 \\
\hline$+0,150$ & $\sum \mathrm{K}$ & 10,86 & 3,49 & 15,35 & 15,35 & 11,36 & 8,89 \\
\hline$-0,150+0,075$ & & 17,95 & 4,32 & 31,41 & 31,41 & 23,24 & 18,82 \\
\hline$-0,075+0,038$ & & 16,89 & 4,49 & 30,72 & 30,72 & 22,68 & 18,40 \\
\hline \multirow[t]{2}{*}{$-0,038+0$} & & 7,38 & 7,52 & 22,52 & 22,52 & 16,66 & 13,47 \\
\hline & & 53,08 & 4,65 & 100,00 & 100,00 & 73,94 & 59,58 \\
\hline$+0,150$ & $\mathrm{~J}$ & 29,22 & 2,35 & 79,04 & & 20,58 & 16,96 \\
\hline$-0,150+0,075$ & & 9,50 & 0,78 & 8,53 & & 2,22 & 1,79 \\
\hline$-0,075+0,038$ & & 3,19 & 1,22 & 4,48 & & 1,21 & 0,94 \\
\hline \multirow[t]{2}{*}{$-0,038+0$} & & 5,01 & 1,38 & 7,95 & & 2,05 & 1,68 \\
\hline & & 46,92 & 1,85 & 100,00 & & 26,06 & 21,37 \\
\hline$+0,150$ & $\mathrm{U}$ & 40,08 & 2,68 & 31,94 & & 31,94 & 25,85 \\
\hline$-0,150+0,075$ & & 27,45 & 3,09 & 25,46 & & 25,46 & 20,61 \\
\hline$-0,075+0,038$ & & 20,08 & 3,97 & 23,89 & & 23,89 & 19,34 \\
\hline \multirow[t]{2}{*}{$-0,038+0$} & & 12,39 & 5,04 & 18,71 & & 18,71 & 15,15 \\
\hline & & 100,00 & 3,34 & 100,00 & & 100,00 & 80,95 \\
\hline
\end{tabular}




\section{RESULTS AND DISCUSSION}

The distribution of solid phase mass in hydrocyclone overflow and underflow, approximately $20: 80 \%$, and higher presence of copper and especially gold in hydrocyclone underflow in relation to hydrocyclone overflow confirms the fact that hydrocyclone, besides classification, also performs a partial concentration of useful components in the function of differrent density. This occurrence is more pronounced with more negative effects in the processing of high-grade copper ore, what confirms the presence of enough ground raw material of size class size $-0.074 \mathrm{~mm}$ in hydrocyclone underflow approximately
$32.47 \%$ as well as significantly higher copper content in this size class, in relation to the content of the same component in the same class of hydrocyclone overflow, Tables 1 and 2 .

Based on the results of divided batch flotation on hydrocyclone overflow and underflow, Tables 5 and 6, Figure 2 shows the copper flotation kinetics from these products of classification. Copper flotation kinetics from hydrocyclone overflow and underflow are shown on diagrams in Figure 2a, while the same indicators, calculated on total copper in feed material, are shown with diagrams in Figure 2b.

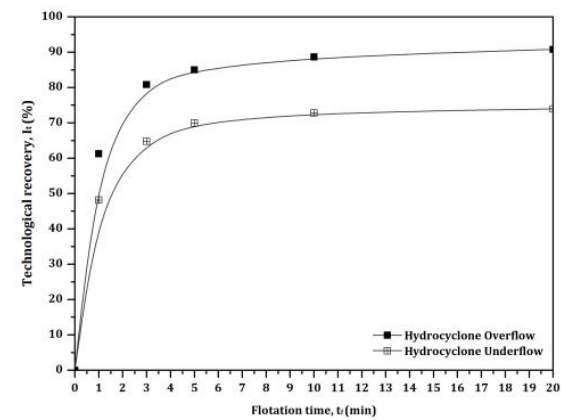

a)

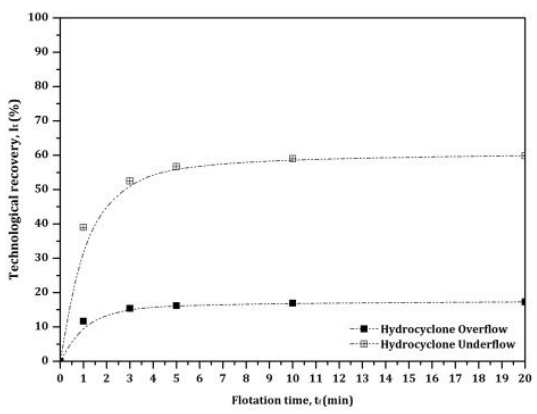

b)

Figure 2 Copper flotation kinetics from hydrocyclone overflow and underflow

a) compared to the copper content in hydrocyclone products,

b) compared to the copper content in hydrocyclone feed

Higher copper recovery from hydrocyclone underflow, approximately $70 \%$, satisfactory flotation kinetics, Figure 2 (a), in particular, several times higher recovery of copper, about $60 \%$ from hydrocyclone underflow, compared to $17.30 \%$ from hydrocyclone overflow in the relation of the copper content in the feed of the hydrocyclone, justified investigation of the possibilities for improvement of processing of the rich copper ore in the Copper Mine Bor.

For a detailed overview of the research results is defined distribution of the copper, both in integral samples and by the narrow classes of the same products, Tables 1 and 2. Copper flotation kinetics are also defined from narrow size classes of hydrocyclone overflow and underflow, diagrams in Figures 3, 4 and 5 . 


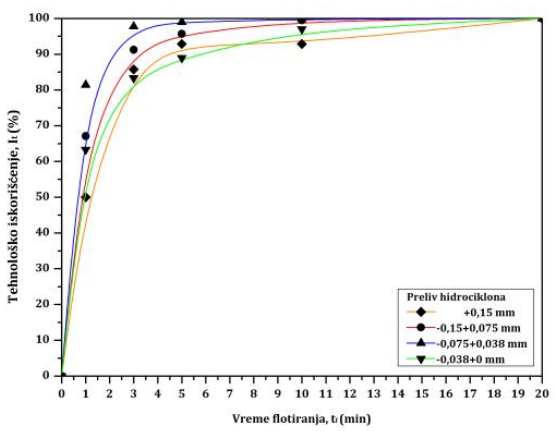

a)

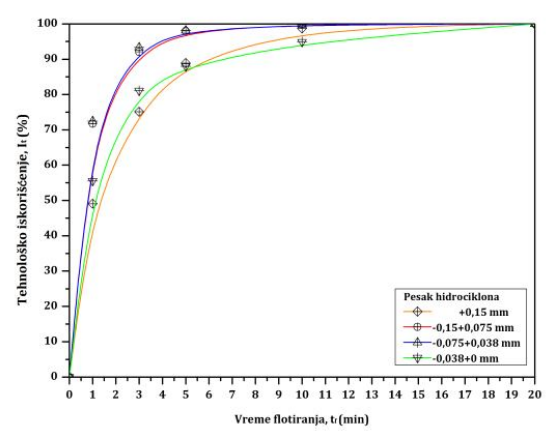

b)

Figure 3 Copper flotation kinetics from narrow size classes a) hydrocyclone overflow, b) hydrocyclone underflow

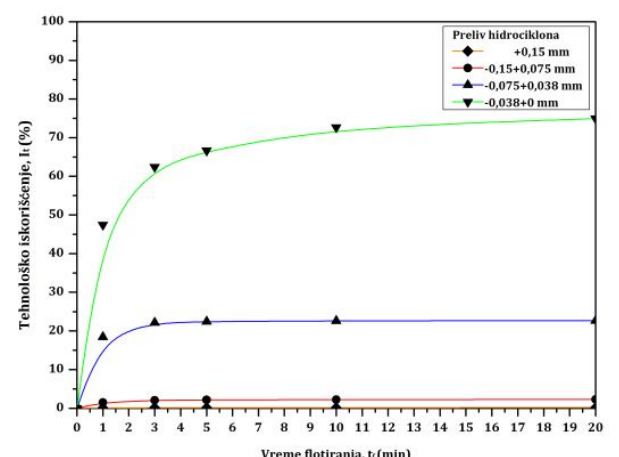

a)

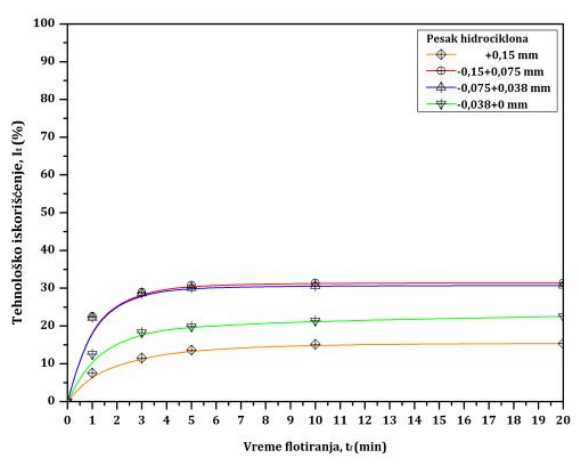

b)

Figure 4 Copper recovery by narrow size classes of classification products a) in hydrocyclone overflow, for IOF $=100 \%, b$ ) in hydrocyclone underflow, IUF $=100 \%$

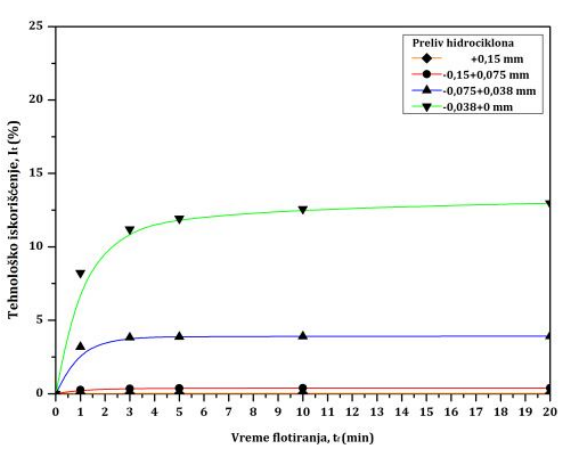

a)

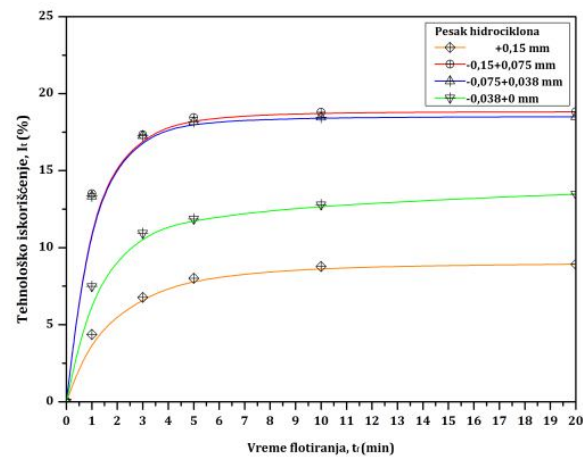

b)

Figure 5 Copper recovery by size classes, compared to the copper content in feed of hydrocyclone: a) hydrocyclone overflow b) hydrocyclone underflow 


\section{CONCLUSION}

The best copper flotation kinetics from hydrocyclone overflow is achieved on class $(-0.075+0.038) \mathrm{mm}$, and hydrocyclone underflow on classes $(-0.150+0.075) \mathrm{mm}$ and $(-0.075+0.038) \mathrm{mm}$, respectively, diagrams in Figure 3 ( $a$ and $b$ ).

Due to copper distribution per certain size classes of classification products, Table 2 and 3, the highest contributio $\mathrm{n}$ to the copper recovery from hydrocyclone overflow is from the finest class $-0.038 \mathrm{~mm}$, approximately $75 \%$, while from the optimal grain size for flotation kinetics, the class $(-0.075+0.038) \mathrm{mm}$, the contribution is realized to total recovery of $22.66 \%$. Contribution to total copper recovery from hydro-cyclone overflow from the other size class is almost insignificant, $2.25 \%$ from the class $(-0.150+0.075) \mathrm{mm}$ and $0.16 \%$ from the class $+0.150 \mathrm{~mm}$. In hydrocyclone underflow, coarser classes have the best flotation kinetics, t diagram in Figure 3 (b), while the contribution to total recovery from narrow size class are more balanced. From the class $(-0.150+0.075) \mathrm{mm}$, contribution is achieved to total recovery of $23.24 \%$, from the class $(-0.075+0.038)$ $\mathrm{mm}$, approximately $22.68 \%$, from the class

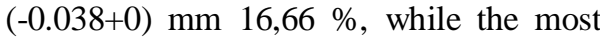
coarser class $+0.150 \mathrm{~mm}$ from hydrocyclone underflow contribute with significant $11.36 \%$ in total recovery.

The results presented on diagram in Figure 5 ( $\mathrm{a}$ and $\mathrm{b}$ ) showing the value of copper in narrow size class of hydrocyclone overflow and underflow, calculated based on total available copper in the feed of cyclone, have particular importance. Besides confirmation the previous conclusions about higher total copper recovery from hydrocyclone underflow, compared to hydrocyclone overflow, Figure 2 (b), it can be concluded that the individual contribution of copper from each class of hydrocyclone underflow is higher than the same indicator, obtained in the same class of hydrocyclone overflow.
The research results clearly confirm the possibility of improving the flotation process of high-grade copper ore, with additional flotation of hydrocyclone underflow. This conclusion is based on the fact that copper distribution in classification product is approximately $20: 80 \%$ in favor of hydrocyclone underflow, higher copper content in integral sample of hydrocyclone underflow, $3.34 \% \mathrm{Cu}$, as compared to hydrocyclone overflow $3.15 \% \mathrm{Cu}$, as well as all narrow size classes of the same product. It is particularly important to note the increased participation and copper content in the optimal liberated classes of hydrocyclone underflow compared to the same class hydrocyclone overflow.

Participation of class $-0.075 \mathrm{~mm}$ in the hydrocyclone underflow is about $32,5 \%$, with copper content of $4.38 \%$, while the participation of the same class in hydrocyclone overflow is about $84.2 \%$ with the content of the same useful component of $3.62 \%$. Compared to the copper contained in this size class in the feed of cyclone, about $65 \%$ is distributed in hydrocyclone underflow and $35 \%$ in the hydrocyclone overflow. The stated facts have shown great overgrinding of raw materials in the industrial process of grinding, as well as inefficiency and clarity of classification, due to inadequate operating parameters, as well as technological imperfections of this device in treatment of polymineral ores with different density.

The results of flotation experiments on hydrocyclone overflow and underflow indicate a few significant occurrences.

Slightly better kinetics and higher copper recovery from hydrocyclone overflow were consequence of increased liberation the solid phase and optimization the pulp density in flotation process. A significant lower contribution of copper from the optimal size class $(0.075+0.038) \mathrm{mm}$ for flota 


\section{REFERENCES}

tion process, compared to the same parameter, was achieved on the finest size class $-0.038 \mathrm{~mm}$, confirming the previous conclusion about overgrinding of raw materials in grinding process. Too high content of the class $-0.075 \mathrm{~mm}$ in hydrocyclone overflow, approximately $84.2 \%$, with about $62 \%$ finer than $0.038 \mathrm{~mm}$, has negative consequences both in the increased energy consumption in grinding process as well as decreased flotation efficiency.

Higher content of optimally liberated size class $(-0.075+0) \mathrm{mm}$ in hydrocyclone underflow, about $32.5 \%$, with participation of class below $0.038 \mathrm{~mm}$ higher than $12 \%$, are indicators of inefficient classification and causes both of sufficient kinetics and high copper recovery in the flotation process from hydrocyclone underflow.

With the statement that in the industrial process of high-grade copper ore, due to continuity of industrial process, the flotation results from hydrocyclone overflow and underflow can be differ from the obtained in the laboratory flotation tests, the real possibility and technological justification can be stated with certainty for improvement the existing technology of high-grade copper ore processing from RTB Bor, with additional flotation of hydrocyclone underflow.
[1] R. Stanojlović, Flotation Device by Dense and Viscous Pulp, Patent No. 46869, 1990.

[2] R. Stanojlović, Z. S. Marković, J. Sokolović, Copper Flotation from Hydrocyclone Underflow - the Significant Improvement of Technological Parameters in Copper Slag Processing, Proceedings of $37^{\text {th }}$ International October Conference on Mining and Metallurgy, Bor, Serbia and Montenegro, (2005), pp. 190-195.

[3] R. Stanojlović, M. Pavlović, J. Sokolović, Z. Štirbanović, Device for Flotation of Dense and Viscous Pulps Pneumo-mechanical Gravity Flotation Machine "Samica RS", Technical Solution, Bor, 2009.

[4] R. Stanojlović, R. Nikolić, J. Sokolović, Z. Štirbanović, D. Antić, Technological Process of Flotation Concentration of Copper and Precious Metals from Underflow and Overflow Hydrocyclone in the Processing of Smelting Slag RB-Bor, Technical Solution, Bor, 2010.

[5] R. Stanojlović, M. Trumić, J. Sokolović, N. Stančev, Flotation of Useful Components from the Hydrocyclone Underflow in the Processing of Rich Copper Ore in the Copper Mine Bor Unsustainable or Sustainable Technological Innovation, Proceedings of $44^{\text {th }}$ International October Conference on Mining and Metallurgy, Bor, Serbia, (2012), pp. 105-110. 


\begin{tabular}{ll}
\hline \hline INSTITUT ZA RUDARSTVO I METALURGIJU BOR & ISSN: 2334-8836 \\
& UDK: 622 \\
\hline \hline
\end{tabular}

Rodoljub Stanojlović, Jovica Sokolovic ${ }^{*}$

\section{ISTRAŽIVANJE KINETIKE FLOTIRANJA PRELIVA I PESKA HIDROCIKLONA PRI PRERADI BOGATE RUDE BAKRA**}

Izvod

Rezultati istraživanja kinetike flotiranja preliva i peska hidrociklona pri preradi bogate rude bakra RB-Bor, upućuju na mogućnost unapređenja postojećeg tehnološkog procesa flotiranja. Raspodela bakra u proizvodima klasiranja $80: 20 \%$, u korist peska hidrociklona, veći sadržaj bakra u uzorku $i$ svakoj klasi peska hidrociklona u odnosu na isti pokazatelj preliva hidrociklona, to potvrđuju.

Učešće optimalno oslobođene klase krupnoće -0,075 mm u pesku hidrociklona od 32,47\%, sa sadržajem bakra od 4,38 \%, rezultiraju da se oko 65 \% od ukupnog bakra koji nosi ova klasa u ulazu u hidrociklon distribuira u pesku, a $35 \%$ u istoj klasi preliva hidrociklona.

Iskorišćenje bakra u opitima flotiranja preliva iznosi 90,77\%, a peska hidrociklona 73,94\%. Obračunato u odnosu na ukupan bakar u ulazu u hidrociklon, flotiranjem preliva hidrociklona valorizuje se $17,30 \% \mathrm{Cu}$, a istim postupkom iz peska hidrociklona se iskoristi $59,58 \% \mathrm{Cu}$, što je 3,44 puta više.

I pored većeg iskorišćenja bakra i nešto bolje kinetike flotiranja preliva hidrociklona zbog bolje oslobođenosti čvrste faze i optimizacije gustine pulpe u procesu flotiranja, svaka klasa peska hidrociklona daje veći doprinos iskorišćenju bakra u odnosu na odgovarajuće klase preliva hidrociklona, obračunato na bakar sadržan u istim klasama ulaza u hidrociklon.

Paralelnim flotiranjem preliva i peska hidrociklona može se unaprediti postojeći tehnološki proces prerade bogate rude bakra RB-Bor.

Ključne reči: Rudnik bakra Bor, bogata ruda bakra, hidrociklon, preliv, pesak, flotacija, kinetika.

\section{UVOD}

Povećan sadržaj bakra, od $2-5 \% \mathrm{Cu}$ i zlata od nekoliko (1 - $7 \mathrm{~g} / \mathrm{t} \mathrm{Au})$, kao i velika razlika u gustinama ovih komponenata $\mathrm{u}$ odnosu na gustine prateće alumosilikatne jalovine, uslovljavaju smanjenu efikasnost oštrine klasiranja u hidrociklonu pri preradi

\footnotetext{
"Univerzitet u Beogradu, Tehnički fakultet u Boru, Vojske Jugoslavije 12, 19210, Bor, Srbija, e-mail: jsokolovic@tf.bor.ac.rs

** U ovom radu su prikazani rezultati projekata TR 33007 „Implementacija savremenijih tehničkotehnoloških i ekoloških rešenja u postojećim proizvodnim sistemima Rudnika bakra Bor i Rudnika bakra Majdanpek“ $i$ TR 33038 „Usavršavanje tehnologija eksploatacije i prerade rude bakra sa monitoringom životne i radne sredine u RTB Bor Grupa" finansiranih od strane Ministarstva prosvete, nauke i tehnološkog razvoja Republike Srbije. Autori se zahvaljuju pomenutom Ministarstvu na finansijskoj podršci.
} 
bogate rude bakra (naš rad). Ova pojava uslovljava da se čestice većih gustina, minerala bakra, $\rho=4100 \mathrm{~kg} / \mathrm{m}^{3}-5800 \mathrm{~kg} / \mathrm{m}^{3}$, i zlata $\rho \approx 19000 \mathrm{~kg} / \mathrm{m}^{3}$, oslobođene i dovoljno usitnjene za proces flotiranja umesto $\mathrm{u}$ preliv distribuiraju u pesak hidrociklona i nepotrebno vraćaju u proces mlevenja [1-5]. Negativne posledice tehničko-tehnološke nesavršenosti hidrociklona kao uređaja za klasiranje su višestruke i ogledaju se u povećanju potrošnje energije i šarže $u$ procesu mlevenja po toni prerađene rude, smanjenju kapaciteta prerade, a preusitnjavanje korisnih komponenata negativno se odražava na iskorišćenje $\mathrm{u}$ procesu flotiranja [1-5].

Masena raspodela čvrste faze i korisnih komponenata u industrijskom procesu prerade ove sirovine od oko $20 \%$ prema $80 \%$ u korist peska hidrociklona, kao i granulometrijske karakteristike ovih proizvoda klasiranja, ukazuju na nedovoljnu efikasnost procesa klasiranja.

Laboratorijskim opitima flotiranja preliva i peska hidrociklona industrijskog procesa prerade bogate rude bakra definisani su tehnološki pokazatelji i kinetike procesa flotacijske koncentracije.
Analiza tehnoloških pokazatelja i kinetika procesa flotiranja, kako na integralnim proizvodima, prelivu i pesku hidrociklona, tako i po uskim klasama krupnoće, uvažavajući industrijsku raspodelu čvrste faze i korisnih komponenata $\mathrm{u}$ istim, omogućava realno sagledavanje opravdanosti istraživanja u pravcu tehnološkog unapređenja postojećeg procesa flotacijske koncentracije bogate rude bakra.

\section{MLEVENJE I KLASIRANJE BOGATE RUDE BAKRA}

Ovaj deo pripreme bogate rude bakra sadrži dvostadijalno mlevenje u mlinu sa šipkama i mlinu sa kuglama, koji radi u zavorenom ciklusu sa hidrociklonom koji služi za klasiranje proizvoda mlevenja. Preliv hidrociklona se kao gotov proizvod mlevenja distribuira $\mathrm{u}$ proces flotacijske koncentracije bakra i plemenitih metala, a pesak hidrociklona se vraća u proces mlevenja u mlin sa kuglama, slika 1.

Kapacitet industrijske prerade bogate rude bakra RB Bor je $80 \mathrm{t} / \mathrm{h}$. Projektovana finoća gotovog proizvoda mlevenja je $60 \%$ učešće klase $-0,074 \mathrm{~mm}$.

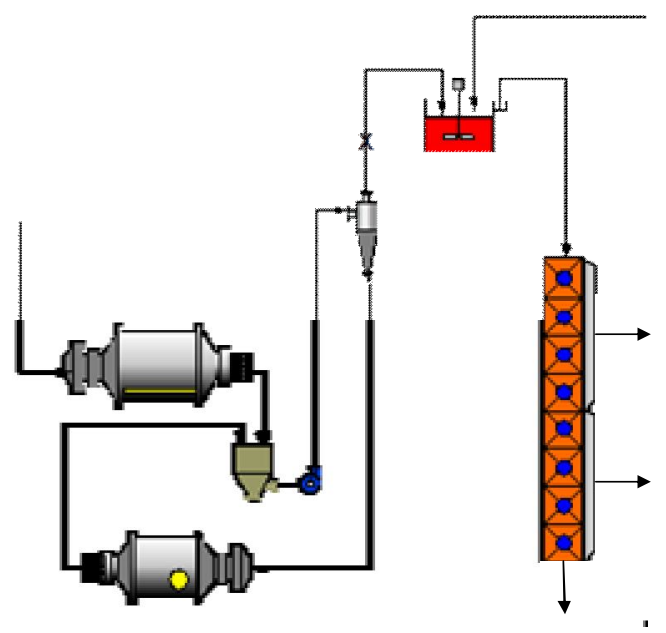

Sl. 1. Šema procesa mlevenja i klasiranja bogate rude bakra 
Snimanjem industrijskog procesa mlevenja i klasiranja bogate rude bakra definisana je raspodela mase čvrste faze i korisnih komponenata u procesu klasiranja, kao i granulometrijski i hemijski sastav proizvoda mlevenja, preliva i peska hidrociklona, tabela 1 i 2.

Tabela 1. Raspodela mase čvrste faze i korisnih komponenata po proizvodima klasiranja

\begin{tabular}{|c|c|c|c|}
\hline \multirow{2}{*}{ Proizvod } & \multicolumn{3}{|c|}{ Raspodela } \\
\cline { 2 - 4 } & Masa čvrste faze (\%) & Bakra Cu (\%) & Zlata Au (\%) \\
\hline Preliv HC & 19,99 & 19,05 & 9,77 \\
\hline Pesak HC & 80,01 & 80,95 & 90,23 \\
\hline Ulaz u HC & 100,00 & 100,00 & 100,00 \\
\hline
\end{tabular}

Tabela 2. Granulometrijski i hemijski sastav proizvoda klasiranja

\begin{tabular}{|c|c|c|c|c|c|c|c|c|c|}
\hline \multirow{2}{*}{$\begin{array}{c}\text { Klasa } \\
\text { krupnoće, } \\
(\mathbf{m m})\end{array}$} & \multicolumn{3}{|c|}{ Preliv HC } & \multicolumn{3}{|c|}{ Pesak HC } & \multicolumn{3}{|c|}{ Ulaz u HC } \\
\hline & $\underset{(\%)}{\mathbf{m}}$ & $\begin{array}{c}\mathrm{Cu} \\
(\%)\end{array}$ & $\begin{array}{l}\mathbf{R}_{\mathrm{Cu}} \\
(\%)\end{array}$ & $\underset{(\%)}{\mathbf{m}}$ & $\begin{array}{c}\mathrm{Cu} \\
(\%)\end{array}$ & $\begin{array}{l}\mathbf{R}_{\mathrm{Cu}} \\
(\%)\end{array}$ & $\mathbf{m}_{(\%)}$ & $\begin{array}{l}\mathrm{Cu} \\
(\%)\end{array}$ & $\begin{array}{l}\mathbf{R}_{\mathrm{Cu}} \\
(\%)\end{array}$ \\
\hline$+0,150$ & 2,11 & 0,38 & 0,25 & 40,08 & 2,68 & 32,12 & 32,49 & 2,65 & 26,05 \\
\hline$-0,150+0,075$ & 13,65 & 0,65 & 2,82 & 27,45 & 3,09 & 25,37 & 24,69 & 2,82 & 21,07 \\
\hline$-0,075+0,038$ & 21,96 & 3,10 & 21,61 & 20,08 & 3,97 & 23,84 & 20,46 & 3,78 & 23,41 \\
\hline$-0,038+0,000$ & 62,28 & 3,81 & 75,32 & 12,39 & 5,04 & 18,67 & 22,36 & 4,36 & 29,47 \\
\hline Ukupno: & 100,00 & 3,15 & 100,00 & 100,00 & 3,34 & 100,00 & 100,00 & 3,31 & 100,00 \\
\hline
\end{tabular}

\section{EKSPERIMENTALNA ISPITIVANJA}

Na uzorcima preliva i peska hidrociklona industrijskog procesa prerade bogate rude bakra izvršeni su opiti flotiranja..

Opiti flotiranja su izvođeni na prelivu i pesku hidrociklona u laboratrorijskoj mašini tipa „Denver“ zapremine 2,6 1, pri aeraciji pulpe od $260 \mathrm{l} / \mathrm{min}$ i agitaciji od $1300 \mathrm{o} / \mathrm{min}$. pH vrednost pulpe iznosila je 10,5. Sadržaji čvrstog u pulpi su iznosili $25 \%$ u opitu flotiranja preliva hidrociklona i $50 \%$ u opitu flotiranja peska hidrociklona. Korišćeni su sledeći reagensi: kolektori KEX (170 g/t u flotaciji preliva hidrociklona) i KAX (350 $\mathrm{g} / \mathrm{t} \mathrm{u}$ flotaciji peska hidrociklona) i Dowfroth D-250 kao penušač $(20 \mathrm{~g} / \mathrm{t})$. Vreme kondi- cioniranja pulpe iznosilo je 10 minuta, nakon čega je dodata potrebna doza flotacijskih reagenasa i pulpa je kondicionirana još jedan dodatni minut. U opitima kinetike flotiranja bakra, flotacijski proizvodi (koncentrati) su dobijeni posle 1, 3, 5, 10 i 20 minuta flotiranja. Proizvodi opita flotiranja, koncentrati i jalovina su prosejavani na odabranoj seriji sita „Tyler“, mokrim postupkom. Nakon sušenja i merenja mase, uzorci pojedinih klasa krupnoce proizvoda flotiranja, su dati na hemijsku analizu. Rezultati raspodele mase čvrste faze i bakra po klasama krupnoće proizvoda flotiranja prikazani su u tabelama 3 i 4 . 
Tabela 3. Granulometrijski i hemijski sastav proizvoda flotiranja preliva hidociklona

\begin{tabular}{|c|c|c|c|c|c|c|c|c|c|}
\hline \multirow{2}{*}{$\begin{array}{c}\text { Klasa } \\
\text { krupnoće, } \\
(\mathbf{m m})\end{array}$} & \multicolumn{3}{|c|}{ Koncentrat } & \multicolumn{3}{|c|}{ Jalovina } & \multicolumn{3}{|c|}{ Ulaz (Preliv HC) } \\
\hline & $\underset{(\%)}{\mathbf{m}}$ & $\begin{array}{c}\mathrm{Cu} \\
(\%)\end{array}$ & $\begin{array}{l}\mathbf{R}_{\mathrm{Cu}} \\
(\%)\end{array}$ & $\underset{(\%)}{\mathbf{m}}$ & $\begin{array}{c}\mathrm{Cu} \\
(\%)\end{array}$ & $\begin{array}{l}\mathbf{R}_{\mathrm{Cu}} \\
(\%)\end{array}$ & $\underset{(\%)}{\mathbf{m}}$ & $\begin{array}{c}\mathrm{Cu} \\
(\%)\end{array}$ & $\begin{array}{l}\mathbf{R}_{\mathrm{Cu}} \\
(\%)\end{array}$ \\
\hline$+0,150$ & 0,24 & 1,92 & 0,16 & 1,87 & 0,18 & 1,17 & 2,11 & 0,38 & 0,25 \\
\hline$-0,150+0,075$ & 2,03 & 3,16 & 2,25 & 11,62 & 0,21 & 13,65 & 13,65 & 0,65 & 2,81 \\
\hline$-0,075+0,038$ & 10,34 & 6,26 & 22,66 & 11,62 & 0,28 & 21,96 & 21,96 & 3,10 & 21,60 \\
\hline$-0,038+0,000$ & 33,89 & 6,32 & 74,93 & 28,39 & 0,81 & 62,28 & 62,28 & 3,81 & 75,34 \\
\hline Ukupno: & 46,50 & 6,14 & 100,00 & 53,50 & 0,54 & 100,00 & 100,00 & 3,15 & 100,00 \\
\hline
\end{tabular}

Tabela 4. Granulometrijski i hemijski sastav proizvoda flotiranja peska hidrociklona

\begin{tabular}{|c|c|c|c|c|c|c|c|c|c|}
\hline \multirow{2}{*}{$\begin{array}{c}\text { Klasa } \\
\text { krupnoće, } \\
(\mathbf{m m})\end{array}$} & \multicolumn{3}{|c|}{ Koncentrat } & \multicolumn{3}{|c|}{ Jalovina } & \multicolumn{3}{|c|}{ Ulaz (Pesak HC) } \\
\hline & $\underset{(\%)}{\mathbf{m}}$ & $\underset{(\%)}{\mathrm{Cu}}$ & $\begin{array}{l}\mathbf{R}_{\mathrm{Cu}} \\
(\boldsymbol{\%})\end{array}$ & $\underset{(\%)}{\mathbf{m}}$ & $\begin{array}{c}\mathrm{Cu} \\
(\%)\end{array}$ & $\begin{array}{l}\mathbf{R}_{\mathrm{Cu}} \\
(\%)\end{array}$ & $\underset{(\%)}{\mathbf{m}}$ & $\underset{(\%)}{\mathrm{Cu}}$ & $\begin{array}{l}\mathbf{R}_{\mathrm{Cu}} \\
(\boldsymbol{\%})\end{array}$ \\
\hline$+0,150$ & 10,86 & 3,49 & 15,36 & 29,22 & 2,35 & 79,04 & 40,08 & 2,68 & 31,94 \\
\hline$-0,150+0,075$ & 17,95 & 4,32 & 31,42 & 9,50 & 0,78 & 8,53 & 27,45 & 3,09 & 25,46 \\
\hline$-0,075+0,038$ & 16,89 & 4,49 & 30,72 & 3,19 & 1,22 & 4,48 & 20,08 & 3,97 & 23,89 \\
\hline$-0,038+0,000$ & 7,38 & 7,52 & 22,50 & 5,01 & 1,38 & 7,95 & 12,39 & 5,04 & 18,71 \\
\hline Ukupno: & 53,08 & 4,65 & 100,00 & 46,92 & 1,85 & 100,00 & 100,00 & 3,34 & 100,00 \\
\hline
\end{tabular}

\section{KINETIKA FLOTIRANJA BAKRA IZ PRELIVA I PESKA HIDROCIKLONA}

Shodno cilju istraživanja, na prelivu i pesku hidrociklona su vršeni opiti razdeljene flotacije u odabranim vremenskim intervalima. Svaki od dobijenih koncentrata i jalovina pojedinih opita flotiranja su nakon sušenja i merenja masa klasirani na odabrane, za proces flotiranja, karakteristične klase krupnoće. Svaka klasa krupnoće pojedinačnih, u funkciji vremena, dobijenih koncentrata i jalovine su analizirani na sadržaj bakra kao osnovne korisne komponente.

$\mathrm{Na}$ osnovu rezultata ispitivanja, prikazanih u tabelama 1-4, preračunate su vrednosti iskorišćenja bakra, kako po uskim klasama krupnoće, tako i integralne vrednosti, $\mathrm{u}$ funkciji vremena flotiranja, kao osnove za definisanje kinetike procesa flotiranja bakra iz preliva i peska hidrociklona. Obračunate vrednosti tehnoloških pokazatelja date su u tabelama 5 i 6. 
Tabela 5. Granulometrijski, hemijski sastav i tehnološki pokazatelji razdeljene flotacije

\begin{tabular}{|c|c|c|c|c|c|c|c|}
\hline \multirow{2}{*}{$\begin{array}{l}\text { Klasa krupnoće } \\
\text { d (mm) }\end{array}$} & \multirow{2}{*}{ Proizvod } & \multirow{2}{*}{$\begin{array}{l}\mathbf{m} \\
(\%)\end{array}$} & \multirow{2}{*}{$\begin{array}{c}\mathrm{Cu} \\
(\%)\end{array}$} & \multirow{2}{*}{$\begin{array}{l}\mathbf{I}_{\mathrm{Cu}} \\
(\%)\end{array}$} & \multicolumn{3}{|c|}{$\mathbf{I}_{\mathrm{Cu}}(\%)$} \\
\hline & & & & & $\mathrm{I}_{\mathrm{k}}=100 \%$ & $\mathrm{I}_{\mathrm{u}}^{\mathrm{p}}=100 \%$ & $\mathrm{I}_{\mathrm{u}}^{\mathrm{c}}=100 \%$ \\
\hline$+0,150$ & \multirow{4}{*}{ K1 } & 0,08 & 2,88 & 0,12 & 0,08 & 0,07 & 0,01 \\
\hline$-0,150+0,075$ & & 0,91 & 4,72 & 2,22 & 1,50 & 1,36 & 0,26 \\
\hline$-0,075+0,038$ & & 6,51 & 8,09 & 27,32 & 18,44 & 16,74 & 3,19 \\
\hline \multirow[t]{2}{*}{$-0,038+0$} & & 13,32 & 10,18 & 70,34 & 47,47 & 43,09 & 8,22 \\
\hline & & 20,82 & 9,26 & 100,00 & 67,49 & 61,26 & 11,68 \\
\hline$+0,150$ & \multirow{4}{*}{ K2 } & 0,09 & 1,82 & 0,26 & 0,06 & 0,05 & 0,01 \\
\hline$-0,150+0,075$ & & 0,64 & 2,43 & 2,52 & 0,54 & 0,49 & 0,09 \\
\hline$-0,075+0,038$ & & 2,68 & 3,95 & 17,21 & 3,70 & 3,36 & 0,64 \\
\hline \multirow[t]{2}{*}{$-0,038+0$} & & 9,20 & 5,35 & 80,01 & 17,23 & 15,64 & 2,98 \\
\hline & & 12,61 & 4,88 & 100,00 & 21,53 & 19,54 & 3,73 \\
\hline$+0,150$ & \multirow{4}{*}{ K3 } & 0,03 & 1,03 & 0,23 & 0,01 & 0,01 & 0,00 \\
\hline$-0,150+0,075$ & & 0,20 & 1,51 & 2,28 & 0,10 & 0,09 & 0,02 \\
\hline$-0,075+0,038$ & & 0,49 & 1,59 & 5,93 & 0,27 & 0,25 & 0,05 \\
\hline \multirow[t]{2}{*}{$-0,038+0$} & & 3,43 & 3,51 & 91,56 & 4,22 & 3,83 & 0,73 \\
\hline & & 4,15 & 3,17 & 100,00 & 4,60 & 4,18 & 0,80 \\
\hline$+0,150$ & \multirow{4}{*}{ K4 } & 0,03 & 1,02 & 0,26 & 0,01 & 0,01 & 0,00 \\
\hline$-0,150+0,075$ & & 0,24 & 1,03 & 2,16 & 0,09 & 0,08 & 0,02 \\
\hline$-0,075+0,038$ & & 0,51 & 1,07 & 4,76 & 0,19 & 0,17 & 0,03 \\
\hline \multirow[t]{2}{*}{$-0,038+0$} & & 4,31 & 2,49 & 92,82 & 3,78 & 3,43 & 0,65 \\
\hline & & 5,09 & 2,27 & 100,00 & 4,07 & 3,69 & $\mathbf{0 , 7 0}$ \\
\hline$+0,150$ & \multirow{4}{*}{ K5 } & 0,01 & 0,61 & 0,15 & 0,00 & 0,00 & 0,00 \\
\hline$-0,150+0,075$ & & 0,04 & 0,84 & 0,45 & 0,01 & 0,01 & 0,00 \\
\hline$-0,075+0,038$ & & 0,15 & 0,97 & 2,26 & 0,05 & 0,04 & 0,01 \\
\hline \multirow[t]{2}{*}{$-0,038+0$} & & 363 & 1,78 & 97,14 & 2,25 & 2,05 & 0,39 \\
\hline & & 3,83 & 1,74 & 100,00 & 2,31 & 2,10 & 0,40 \\
\hline$+0,150$ & \multirow{4}{*}{$\sum \mathrm{K}$} & 0,24 & 1,92 & 0,16 & 0,16 & 0,14 & 0,02 \\
\hline$-0,150+0,075$ & & 2,03 & 3,16 & 2,25 & 2,25 & 2,03 & 0,39 \\
\hline$-0,075+0,038$ & & 10,34 & 6,26 & 22,66 & 22,66 & 20,56 & 3,92 \\
\hline \multirow[t]{2}{*}{$-0,038+0$} & & 33,89 & 6,32 & 74,93 & 74,93 & 68,04 & 12,97 \\
\hline & & 46,50 & 6,14 & 100,00 & 100,00 & 90,77 & 17,30 \\
\hline$+0,150$ & \multirow{4}{*}{$\mathrm{J}$} & 1,87 & 0,18 & 1,17 & & 0,11 & 0,02 \\
\hline$-0,150+0,075$ & & 11,62 & 0,21 & 8,40 & & 0,76 & 0,15 \\
\hline$-0,075+0,038$ & & 11,62 & 0,28 & 11,19 & & 1,03 & 0,20 \\
\hline \multirow[t]{2}{*}{$-0,038+0$} & & 28,39 & 0,81 & 79,24 & & 7,33 & 1,38 \\
\hline & & 53,50 & 0,54 & 100,00 & & 9,23 & 1,75 \\
\hline$+0,150$ & \multirow{5}{*}{$\mathrm{U}$} & 2,11 & 0,38 & 0,25 & & 0,25 & 0,04 \\
\hline$-0,150+0,075$ & & 13,65 & 0,65 & 2,81 & & 2,79 & 0,54 \\
\hline$-0,075+0,038$ & & 21,96 & 3,10 & 21,60 & & 21,59 & 4,12 \\
\hline \multirow[t]{2}{*}{$-0,038+0$} & & 62,28 & 3,81 & 75,34 & & 75,37 & 14,35 \\
\hline & & 100,00 & 3,15 & 100,00 & & 100,00 & 19,05 \\
\hline
\end{tabular}


Tabela 6. Granulometrijski, hemijski sastav i tehnološki pokazatelji razdeljene flotacije peska hidrociklona

\begin{tabular}{|c|c|c|c|c|c|c|c|}
\hline \multirow{2}{*}{$\begin{array}{c}\text { Klasa krupnoće } \\
\text { d (mm) }\end{array}$} & \multirow{2}{*}{ Proizvod } & \multirow{2}{*}{ m $(\%)$} & \multirow{2}{*}{$\begin{array}{c}\mathrm{Cu} \\
(\%)\end{array}$} & \multirow{2}{*}{$\mathbf{I}_{\mathrm{Cu}}(\%)$} & \multicolumn{3}{|c|}{$\mathbf{I}_{\mathrm{Cu}}(\%)$} \\
\hline & & & & & $\mathrm{I}_{\mathrm{k}}=100 \%$ & $\mathrm{I}_{\mathrm{u}}^{\mathrm{p}}=100 \%$ & $\mathrm{I}_{\mathrm{u}}^{\mathrm{c}}=100 \%$ \\
\hline$+0,150$ & \multirow{4}{*}{$\mathrm{K} 1$} & 5,55 & 3,47 & 11,19 & 7,81 & 5,78 & 4,37 \\
\hline$-0,150+0,075$ & & 12,75 & 4,36 & 34,60 & 22,53 & 16,67 & 13,50 \\
\hline$-0,075+0,038$ & & 12,32 & 4,46 & 34,20 & 22,27 & 16,44 & 13,34 \\
\hline \multirow[t]{2}{*}{$-0,038+0$} & & 3,50 & 8,82 & 19,21 & 12,52 & 9,25 & 7,49 \\
\hline & & 34,12 & 4,71 & 100,00 & 65,13 & 48,14 & 39,00 \\
\hline$+0,150$ & \multirow{4}{*}{$\mathrm{K} 2$} & 2,60 & 3,80 & 17,75 & 4,00 & 2,96 & 2,40 \\
\hline$-0,150+0,075$ & & 3,85 & 4,10 & 28,36 & 6,40 & 4,73 & 3,83 \\
\hline$-0,075+0,038$ & & 3,58 & 4,41 & 28,37 & 6,40 & 4,73 & 3,83 \\
\hline \multirow[t]{2}{*}{$-0,038+0$} & & 1,44 & 9,86 & 25,52 & 5,76 & 4,26 & 3,45 \\
\hline & & 11,47 & 4,85 & 100,00 & 22,56 & 16,68 & 13,51 \\
\hline$+0,150$ & \multirow{4}{*}{$\mathrm{K} 3$} & 1,30 & 3,95 & 29,81 & 2,08 & 1,54 & 1,25 \\
\hline$-0,150+0,075$ & & 0,91 & 5,04 & 26,67 & 1,86 & 1,38 & 1,11 \\
\hline$-0,075+0,038$ & & 0,69 & 5,35 & 21,44 & 1,50 & 1,11 & 0,90 \\
\hline \multirow[t]{2}{*}{$-0,038+0$} & & 0,53 & 7,18 & 22,08 & 1,54 & 1,15 & 0,92 \\
\hline & & 3,43 & 5,02 & 100,00 & 6,98 & 5,18 & 4,18 \\
\hline$+0,150$ & \multirow{4}{*}{ K4 } & 1,18 & 2,66 & 32,81 & 1,27 & 0,94 & 0,76 \\
\hline$-0,150+0,075$ & & 0,38 & 3,77 & 14,94 & 0,58 & 0,43 & 0,35 \\
\hline$-0,075+0,038$ & & 0,24 & 4,93 & 12,33 & 0,48 & 0,35 & 0,29 \\
\hline \multirow[t]{2}{*}{$-0,038+0$} & & 0,90 & 4,25 & 39,92 & 1,55 & 1,15 & 0,93 \\
\hline & & 2,70 & 3,54 & 100,00 & 3,88 & 2,87 & 2,32 \\
\hline$+0,150$ & \multirow{4}{*}{ K5 } & 0,23 & 2,06 & 13,13 & 0,19 & 0,14 & 0,11 \\
\hline$-0,150+0,075$ & & 0,06 & 1,82 & 3,07 & 0,04 & 0,03 & 0,03 \\
\hline$-0,075+0,038$ & & 0,06 & 3,04 & 5,03 & 0,07 & 0,05 & 0,04 \\
\hline \multirow[t]{2}{*}{$-0,038+0$} & & 1,01 & 2,79 & 78,77 & 1,15 & 0,85 & 0,69 \\
\hline & & 1,36 & 2,63 & 100,00 & 1,45 & 1,07 & 0,87 \\
\hline$+0,150$ & \multirow{4}{*}{$\sum \mathrm{K}$} & 10,86 & 3,49 & 15,35 & 15,35 & 11,36 & 8,89 \\
\hline$-0,150+0,075$ & & 17,95 & 4,32 & 31,41 & 31,41 & 23,24 & 18,82 \\
\hline$-0,075+0,038$ & & 16,89 & 4,49 & 30,72 & 30,72 & 22,68 & 18,40 \\
\hline \multirow[t]{2}{*}{$-0,038+0$} & & 7,38 & 7,52 & 22,52 & 22,52 & 16,66 & 13,47 \\
\hline & & 53,08 & 4,65 & 100,00 & 100,00 & 73,94 & 59,58 \\
\hline$+0,150$ & \multirow{4}{*}{$\mathrm{J}$} & 29,22 & 2,35 & 79,04 & & 20,58 & 16,96 \\
\hline$-0,150+0,075$ & & 9,50 & 0,78 & 8,53 & & 2,22 & 1,79 \\
\hline$-0,075+0,038$ & & 3,19 & 1,22 & 4,48 & & 1,21 & 0,94 \\
\hline \multirow[t]{2}{*}{$-0,038+0$} & & 5,01 & 1,38 & 7,95 & & 2,05 & 1,68 \\
\hline & & 46,92 & 1,85 & 100,00 & & 26,06 & 21,37 \\
\hline$+0,150$ & \multirow{4}{*}{$\mathrm{U}$} & 40,08 & 2,68 & 31,94 & & 31,94 & 25,85 \\
\hline$-0,150+0,075$ & & 27,45 & 3,09 & 25,46 & & 25,46 & 20,61 \\
\hline$-0,075+0,038$ & & 20,08 & 3,97 & 23,89 & & 23,89 & 19,34 \\
\hline \multirow[t]{2}{*}{$-0,038+0$} & & 12,39 & 5,04 & 18,71 & & 18,71 & 15,15 \\
\hline & & 100,00 & 3,34 & 100,00 & & 100,00 & 80,95 \\
\hline
\end{tabular}




\section{REZULTATI I DISKUSIJA}

Raspodela mase čvrste faze u prelivu i pesku hidrociklona od cca 20:80 \%, kao i veća zastupljenost bakra, a posebno zlata u pesku u odnosu na preliv hidrociklona potvrđuju činjenice da hidrociklon pored klasifikacije vrši i delimičnu koncentraciju komponenata u funkciji različitih gustina. Ova pojava je izraženija i sa mnogo više negativnih efekata pri preradi bogate rude bakra, što potvrđuje velika zastupljenost dovoljno usitnjene sirovine klase krupnoće $0,074 \mathrm{~mm}$ u pesku hidrociklona od cca $32,47 \%$, kako i znatno veći sadržaj bakra u ovoj klasi krupnoće peska, u odnosu na sadržaj iste komponente u istoj klasi preliva hidrociklona, tabela 1 i 2.

$\mathrm{Na}$ osnovu rezultata laboratorijskih opita razdeljene flotacije preliva i peska hidrociklona, tabela 5 i 6 , na slici 2 su prikazane kinetike flotiranja bakra iz ovih proizvoda cikloniranja. Kinetike flotiranja bakra iz preliva i peska hidrociklona prikazane su dijagramima na slici $2 \mathrm{a}$, dok su isti pokazatelji preračunati na sadržaj bakra u ulaznoj sirovini, prikazani dijagramima na slici $2 b$.

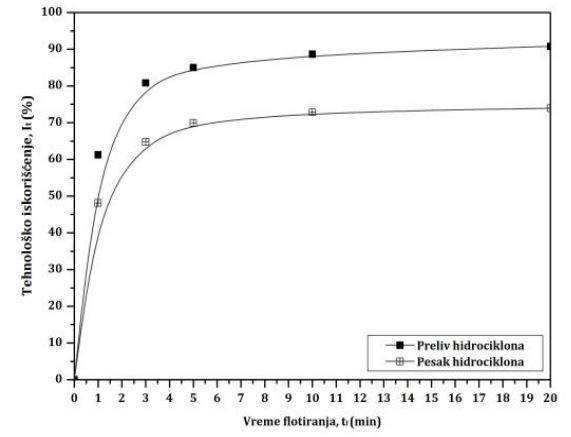

a)

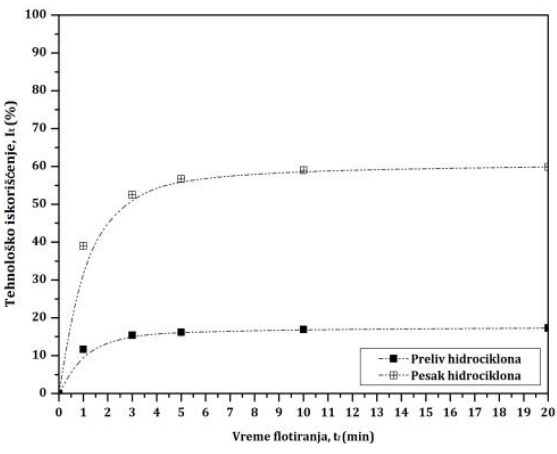

b)

Sl. 2. Kinetika flotiranja bakra iz preliva i peska hidrociklona:

a) u odnosu na sadržaj bakra u proizvodima ciklona, b) u odnosu na sadržaj bakra u ulazu u ciklon

Veliko iskorišćenje bakra iz peska hidrociklona, cca $70 \%$, zadovoljavajuća kinetika flotiranja, dijagram 2 (a), a posebno, višestruko veće iskorišćenje bakra, oko $60 \%$ iz peska, u odnosu na 17,30 \% iskorišćenja iz preliva hidrociklona u odnosu na sadržaj bakra u ulazu u ciklon, opravdavaju istraživanja mogućnosti unapređenja tehnologije prerade bogate rude bakra RB-Bor. U cilju studioznijeg sagledavanja rezultata istraživanja, definisana je raspodela bakra, kako u integralnim uzorcima, proizvodima klasiranja, tako i po uskim klasama istih proizvoda, tabela 1 i 2 . Takođe, su definisane kinetike flotiranja bakra iz uskih klasa krupnoće preliva i peska hidrociklona, dijagrami na slikama 3, 4 i 5. 


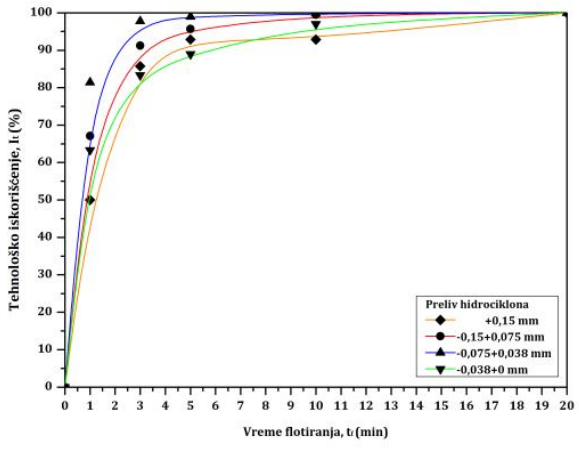

a)

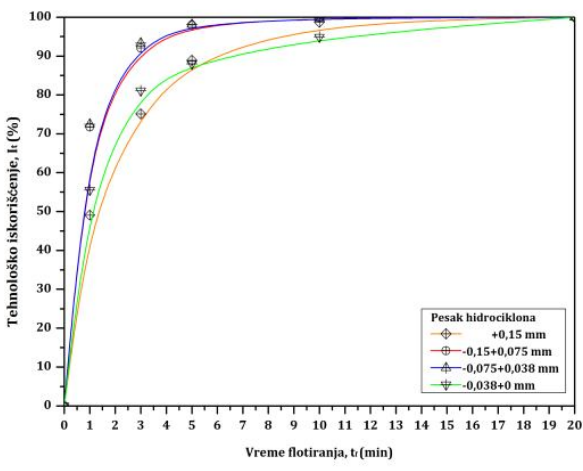

b)

SI. 3. Kinetika flotiranja bakra iz uskih klasa krupnoće: a) preliva hidrociklona, b) peska hidrociklona

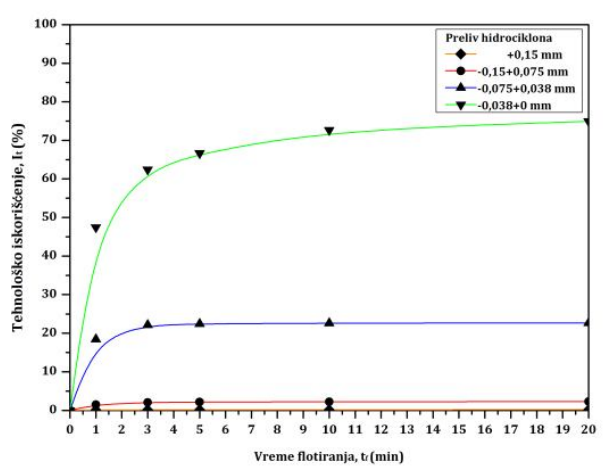

a)

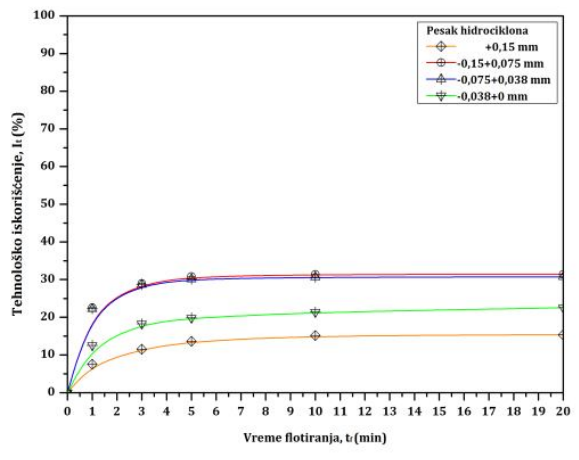

b)

Sl. 4. Iskorišćenja bakra po uskim klasama krupnoće proizvoda klasiranja a) u prelivu hidrociklona, za IPs $=100 \%$, b) u pesku hidrociklona, za IPr $=100 \%$

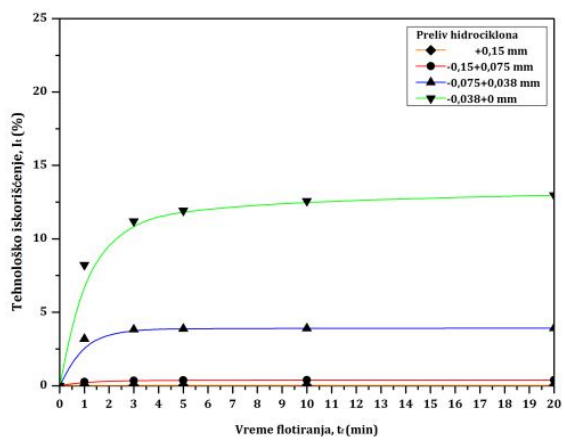

a)

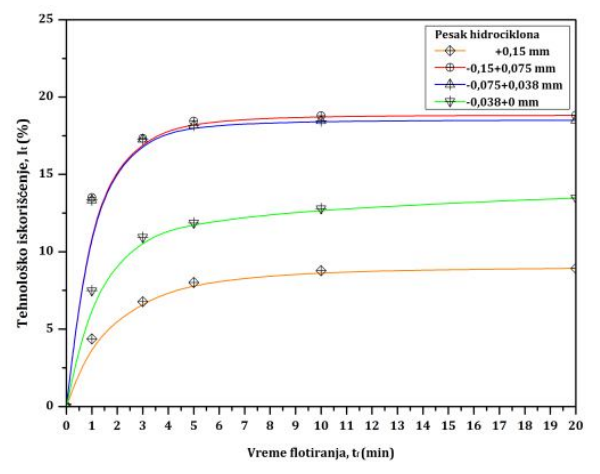

b)

Sl. 5. Iskorišćenje bakra po klasama krupnoće u odnosu na sadržaj bakra u ulazu u hidrociklon a) preliv hidrociklona, b) pesak hidrociklona 


\section{ZAKLJUČAK}

Najbolja kinetika flotiranja bakra iz preliva hidrociklona ostvaruje se na klasi $(-0,075+0,038) \mathrm{mm}$, a na pesku hidrociklona na klasama $(-0,150+0,075) \mathrm{mm}$ i klasi $(-0,075+0,038) \mathrm{mm}$, dijagrami na slici 3 (a i b)

Zbog raspodele bakra po pojedinim klasama krupnoće proizvoda klasiranja, tabela 2 i 3, najveći doprinos iskorišćenju bakra iz preliva hidrociklona ostvaruje se iz najfinije klase, $-0,038 \mathrm{~mm}$, cca $75 \%$, dok se iz optimalne po krupnoći i kinetici procesa flotiranja, klasi $(-0,075+0,038) \mathrm{mm}$, ostvaruje doprinos ukupnom iskorišćenju od 22,66 \%. Doprinos ukupnom iskorišćenju bakra iz preliva hidrociklona iz ostalih klasa krupnoće je skoro zanemarljiv, 2,25\% iz klase $(-0,150+0,075) \mathrm{mm}$ i $0,16 \%$ iz klase $+0,150 \mathrm{~mm}$. U pesku hidrociklona nešto krupnije klase imaju najbolju kinetiku flotiranja, dijagram na slici 3 (b), dok je doprinos ukupnom iskorišćenju uskih klasa krupnoće ravnomerniji. Iz klase $(-0,150+0,075) \mathrm{mm}$ ostvaruje se doprinos ukupnom iskorišćenju od $23,24 \%$, iz klase $(-0,075+0,038) \mathrm{mm}$, oko $22,68 \%$, iz klase $(-0,038+0) \mathrm{mm}$ $16,66 \%$, dok se iz najkrupnije klase $+0,150$ mm ukupnom iskorišćenju iz peska hidrociklona doprinosi sa značajnih 11,36 \%.

Od posebnog značaja su rezultati prikazani dijagramima na slici 5 (a i b), kojima su prikazane vrednosti iskorišćenja bakra po uskim klasama krupnoće preliva i peska hidrociklona, preračunate u odnosu na ukupno raspoloživi bakar u ulazu u ciklon. Pored potvrde predhodne konstatacije o većem ukupnom iskorišćenju bakra iz peska u odnosu na preliv hidrociklona, slika 2 (b), može se konstatovati da je i pojedinačni doprinos iskorišćenju bakra iz svake klase peska hidrociklona veći $\mathrm{u}$ odnosu na isti pokazatelj koji se ostvaruje u istim klasama preliva hidrociklona.
Rezultati istraživanja nedvosmisleno potvrđuju mogućnost unapređenja procesa flotiranja bogate rude bakra, dodatnim flotiranjem peska hidrociklona. Ova konstatacija je zasnovana na činjenicama da je raspodela bakra u proizvodima klasiranja cca $20: 80 \%$, u korist peksa hidrociklona, većem sadržaju bakra kako u integralnom uzorku peska hidrociklona, 3,34 \% Cu, u prelivu $3,15 \% \mathrm{Cu}$, tako i u svim uskim klasama krupnoće istog proizvoda. Posebno je značajno istaći povećano učešće $\mathrm{i}$ sadržaj bakra u optimalno oslobođenim klasama peska $\mathrm{u}$ odnosu na iste klase preliva hidrociklona.

Učešće klase $-0,075 \mathrm{~mm}$ u pesku hidrociklona iznosi oko $32,5 \%$, sa sadržajem bakra od 4,38 \%, dok je učešće iste klase u prelivu hidrociklona oko $84,2 \%$, sa sadržajem iste korisne komponente od 3,62 \%. U odnosu na bakar sadržan u ovoj klasi krupnoće ulaza u ciklon, oko $65 \%$ se distribuira $\mathrm{u}$ pesku a $35 \%$ u prelivu hidrociklona. Navedene činjenice pokazuju veliko preusitnjavanje sirovine, $\mathrm{u}$ industrijskom procesu mlevenja, kao i nedovoljnu efikasnost i oštrinu klasiranja, kako zbog neadekvatnih radnih parametara, tako i tehnološke nesavršenosti ovog uređaja pri tretiranju polimineralnih sirovina različitih gustina.

Rezultati opita flotiranja preliva i peska hidrociklona ukazuju na nekoliko značajnih pojava.

Nešto bolja kinetika i veće iskorišćenje bakra iz preliva hidrociklona su posledica veće oslobođenosti čvrste faze i optimizacije gustine pulpe u procesu flotiranja. Značajno manji doprinos iskorišćenju bakra, iz opti-malne za proces flotiranja, klase $(-0,075+0,038) \mathrm{mm}$, u odnosu na isti pokazatelj ostvaren na najfinijoj klasi krupnoć - 0,038 mm, potvrđuju predhodnu konstataciju o preusitnjavanju sirovine $\mathrm{u}$ 


\section{LITERATURA}

procesu mlevenja. Prevelik sadržaj klase - $0,075 \mathrm{~mm} \mathrm{u}$ prelivu hidrociklona, cca $84,2 \%$, od kojih je oko $62 \%$ finije od 0,038 $\mathrm{mm}$, imaju negativne posledice kako u povećanoj potrošnji energije u procesu mlevenja tako i smanjenoj efikasnosti flotiranja.

Povećan sadržaj optimalno oslobođene klase krupnoće $-0,075 \mathrm{~mm}$ u pesku hidrociklona, od oko $32,5 \%$, sa učešćem klase $-0,038 \mathrm{~mm}$ većim od $12 \%$, su kako pokazatelji neefikasnog klasiranja tako i uzročnici kako zadovoljavajuće kinetike, tako i visokom iskorišćenju bakra u procesu flotiranja peska hidrociklona.

Uz konstataciju da bi se $u$ industrijskom procesu prerade bogate rude bakra, zbog kontinualnosti procesa, rezultati flotiranja preliva i peska hidrociklona razlikovali $\mathrm{u}$ odnosu na laboratorijski dobijene, sa sigurnošću se može konstatovati relna mogućnost i tehnološka opravdanost unapređenju postojeće tehnologije prerade bogate rude bakra RTB-a Bor, dodatnim flotiranjem peska hidrociklona.
[1] R. Stanojlović, Uređaj za flotaciju u gustim i viskoznim pulpama, Patent br. 46869, 1990.

[2] R. Stanojlović, Z. S. Marković, J. Sokolović, Copper Flotation from Hydrocyclone Underflow - the Significant Improvement of Technological Parameters in Copper Slag Processing, Proceedings of $37^{\text {th }}$ International October Conference on Mining and Metallurgy, Bor, Serbia and Montenegro, (2005), str. 190-195.

[3] R. Stanojlović, M. Pavlović, J. Sokolović, Z. Štirbanović, Uređaj za flotaciju u gustim i viskoznim pulpama pneumomehanička - gravitaciona flotacijska mašina "Samica RS, Tehničko rešenje, Bor, 2009.

[4] R. Stanojlović, R. Nikolić, J. Sokolović, Z. Stirbanović, D. Antić, Tehnološki postupak flotacijske koncentracije bakra i plemenitih metala iz preliva i peska hidrociklona pri preradi topioničke šljake RB-Bor, Tehničko rešenje, Bor, 2010.

[5] R. Stanojlović, M. Trumić, J. Sokolović, N. Stančev, Flotation of Useful Components from the Hydrocyclone Underflow in the Processing of Rich Copper ore in the Copper Mine Bor Unsustainable or Sustainable Technological Innovation, Proceedings of $44^{\text {th }}$ International October Conference on Mining and Metallurgy, Bor, Serbia, (2012), str. 105-110. 